\title{
The Role of the College Library Staff In Instruction in the Use of the Library
}

By E. J. JOSEY

$\mathrm{T}$ HE LIBRARY undergirds the instructional program of the college. It cannot be separated from the professors or the curriculum. Someone has said that we can dispense with the faculty and rely solely on the college library, and students will continue to be educated, but this is not the prevailing view. In many institutions of higher learning, there is the idea that students will learn without using the library or knowledge of the use of the library. However, it is the firm conviction of this writer that both the faculty and the college library are equally important in the education of college students. The faculty stimulates intellectual curiosity and critical thinking, while the library, through its resources, provides the intellectual sustenance which can be found only in books.

If it is true that intellectual sustenance is housed in the college library, then it is equally true that knowledge of the use of the library is important in the education of college students. The annual output of the world of publishing is enormous. Current publishing, coupled with the scholarship of yesteryear that is found in antiquarian books, as well as information in the old and current periodicals, staggers the imagination. It is sheer folly for college libraries to spend thousands of dollars to assemble these materials, while at the same time no concrete efforts are made to instruct college students in the use of these materials.

\section{Purpose of the Study}

Savannah State College moved into its new library in the fall of 1959. The im-
Mr. Josey is Librarian at Savannah State College Library, Savannah, Georgia. His master's degree in library science is from New York State College for Teachers, Albany.

posing new structure with its spacious reference department and reading rooms stimulated library use. The former cramped quarters had been an impediment to good library service. Now, for the first time in the history of the college, the library staff had adequate space to confer with and offer reference assistance to students. It was soon appparent that many students, including upperclassmen, were woefully unaware of how to use a simple basic tool such as the Readers Guide to Periodical Literature. The stark realization that graduating seniors did not know how to use the card catalog, ${ }^{1}$ as revealed from a study conducted by the catalog librarian, also helped to ignite the fire.

The librarian placed the problem before the library committee. It was discovered that the English department was responsible for a unit on the use of the library in Humanities 101. Instructors did their teaching in the classrooms without consultation with the library. After serious deliberations, the committee unanimously adopted the following recommendation and instructed the librarian to inform the chairman of the English department:

The Library Committee recommends that the library staff be included for

1 Madeline G. Harrison, "Status of Card Catalog Use at Savannah State College Library," Savannah State College Faculty Research Bulletin, XIV (December 1960) 5-9. 
one class period in the instruction in the use of the library as it appears in Humanities 101. This instruction should take place in the library so that the students may have personal contact with the reference tools.

The librarian and his staff were not satisfied with the "one class period" recommendation, but in spite of its apparent limited consideration, it was an initial step in the right direction. However, we were not prepared for the tempest in the teapot which followed. The librarian informed the English department of the library committee's recommendation, and the chairman of the English department returned the following reply:

'... May I request you to inform the Library Committee that the English Department has already given serious consideration to library orientation in its freshman classes. This consideration is based upon our professional knowledge of the nature of freshman English courses and what constitutes content and procedures in said courses. Accordingly, the members of the department, in light of their experiences, training and background, and in light of individuality in each course, in terms of its constituents and the methodology employed by the instructor, decided that they will work individually with students in their classes according to course outlines in Humanities 101 and 102. And further that members of the Department of English will continue to work with students in their classes in the use of the library in connection with specific assignments requiring such use.

"You will note that the attitude of the department is student-centered and course-centered, not library-centered. As I mentioned to you in an earlier conversation, knowledge of library tools is simply one small phase of information dispensed in Humanities 101 and 102, not the main focus. We are certainly aware of the fact that all students at Savannah State College should have some competence in library usage, but, departmentally, we do not assume the responsibility of bringing light where there may be darkness in this matter, which is college-wide, not merely a matter for the English Department to summarily solve in $\mathrm{Hu}$ manities 101 and Humanities 102.

"But please be assured, the members of the department are aware of the problem and will work on this matter from three points (as indicated throughout this letter): (1) the individual student as the need arises, (2) the nature of the individual course and the teacher's method of conducting that course, and (3) accepted professional standards and practices in teaching English in College."2

The foregoing letter from the chairman of the English department, and several unsuccessful attempts to confer with him, led this writer to devise an instrument to determine the extent of instruction in library use in a group of institutions of higher education. In addition, an effort was made to assess the role of the library staff in the process.

\section{METHODOLOGY}

In the spring of 1961 , the writer sent a questionnaire to 500 college and university library administrators throughout the United States. The librarians represented institutions of various sizes and types, i.e., large public universities, large privately-endowed universities, liberal arts colleges, teachers' colleges, prestige institutions, and less-known institutions.

Eight questions were posed and respondents were requested to check yes or no. (1) The reference librarian or a member of the staff is responsible for a course in the use of the library. (2) A member of the library staff gives one lecture or a series of lectures in connection with freshman orientation week. (3) Library instruction is given as a unit in the freshman English course, and

2 Letter from the chairman, Department of English, Savannah State College, January 15, 1960. 
classes are brought to the library for a series of lectures in connection with or one lecture by the library staff. (4) Formal instruction is given by the library staff to freshman students in a subject area other than English. (5) If the instruction is not given in conjunction with the English courses, indicate whether instruction is given to freshman students by the library staff with class work in subject courses at a time when the students are most likely to be using the materials. (6) Instruction in the use of the library is coordinated with the work of the library. (7) Do you feel that freshman library instruction should be given by members of the teaching faculty without the cooperation of the librarian and his staff? (8) Although instruction in library use is handled by the library staff, there is wholehearted faculty planning and participation.

Library literature abounds with descriptions of successful library-staff taught programs, but very little has been done in the area of faculty controled programs or assessing the role of the library staff in the teaching process. There is no need for a review of the literature, for Bonn has surveyed the literature thoroughly. ${ }^{3}$

\section{Findings}

The findings were varied and revealing. Librarians felt so keen about the problem of instructing college freshman students in the use of the library that many were not content to check the questionnaire alone. They also wrote letters to clarify their views. Of the $\mathbf{5 0 0}$ libraries canvassed, 397 or 79 per cent responded. In view of the high percentage of returns, the findings are significant.

Concerning question one, 239 or 60 per cent of the respondents reported that the reference librarian or a mem-

\footnotetext{
${ }^{3}$ George S. Bonn, Training Laymen In the Use of the Library. (New Brunswick, N. J.: Graduate School of Library Service, Rutgers-The State University, 1960) pp. $27 \cdot 54$.
}

ber of the library staff was not responsible for teaching a course in the use of the library to freshman students, while 107 or 27 per cent indicated that they offered such a course; 51 or 13 per cent gave no response.

With regard to question two, 177 librarians or 45 per cent indicated that a member of the library staff gave one lecture in the use of the library during orientation week; 75 or 19 per cent presented several lectures during the orientation period, while 145 or 36 per cent failed to check the question. The results of question number two are not too conclusive, in view of the fact that a large number of librarians (36 per cent) failed to check the question, but if we consolidate the 177 librarians who present one lecture during the orientation week and the 75 librarians who provide several, then 64 per cent of the respondents participate in some kind of orientation program. Most of the orientation week programs were no more than guided tours. Therefore, orientation week is used to a large extent to introduce students to the location of the library and in some instances, for elementary instruction.

In spite of this high percentage of participation as reported here, many librarians have misgivings of orientation week programs. This point of view is expressed by the associate director of the University of Nebraska libraries who warns, "We must overcome the general idea that library instruction is something that can be tacked on a one-day orientation program. . . ."4

Regarding question three, which is concerned with library instruction given as a unit in the freshman English course, 118 or 30 per cent indicated that one lecture is given to English classes by library staff; 103 or 26 per cent give a series of lectures by the library staff English classes and 176 or 44 per cent

\footnotetext{
4 Letter from Richard A. Farley, associate director of libraries, University of Nebraska, April 14, 1961.
} 
did not present lectures in connection with English classes, while 20 failed to respond. Combining the single lectures and a series of lectures given in conjunction with English classes, we find that 221 academic libraries, or 56 per cent of the libraries surveyed, give instruction in the use of the library to English classes.

Teaching freshmen the use of the library in conjunction with English courses seems to be the preference of the majority of the respondents. Nevertheless, librarians are not completely satisfied with this arrangement. The librarian of the University of North Dakota writes, "Our instruction in library use is done in the freshman English course by the instructors in the English department and classes are then brought to the library for a test in library materials and use, which is compiled by the library staff but administered by the English instructor. During the taking of this test the library staff and sometimes the instructor are available to assist the students and offer explanation and further information. We do not feel that this is a very satisfactory means of accomplishing library instruction. In the first place, the responsibility of the individual instructor is met with varying degrees of enthusiasm and competence. Second, the library test seems to be viewed by students rather as a hurdle to be crossed than as a useful adjunct to studies in all fields. Third, because of this student attitude, there seems to be a minimal amount of actual acquaintance with library tools, plus copying of answers from others with similar questions, and other time-saving short cuts." 5

Although a semblance of cooperation exists between the English department and the library in a large southern university, the respondent writes "This year we changed our program and now have only a thirty-minute televised pic-

5 Letter from Donald J. Pearce, head librarian, Uni. versity of North Dakota, April 4, 1961. ture (not enough, but all allowed by the English department) ... I, personally, am not satisfied with the televised class as it is now handled, but it will be difficult to convince the English department that more time is needed."

Several librarians in their letters indicated that efforts were being made to improve the instruction in English classes. One healthy sign comes from the librarian of Western Michigan University. Miss Stokes reports, "This summer the educational TV staff of the university expects to work with the English faculty and the library staff to prepare a tape to be used for library orientation in English classes. We have high hopes of this being a much better solution than our previous attempts." 7

Question four sought to elicit whether formal library instruction is given by the library staff to freshman students in a subject area other than English. Answering this query, we find 90 librarians or 23 per cent who responded affirmatively, while 272 librarians or 68 per cent replied negatively and 35 librarians or 9 per cent ignored the question. It appears that for all intents and purposes English seems to be the desired vehicle for instructing freshman students in the use of the library.

Librarians were requested in question five to denote that if instruction is not given in conjunction with the English courses, whether it is given by the library staff, with class work in subject courses at a time when the students are most likely to be using the materials. Their answers revealed that 137 or 34 per cent marked yes, 166 or 42 per cent marked no, while 94 or 24 per cent did not answer. These results pointedly call attention to the fact that the majority of the respondents give the instruction when the students are not using the library for research purposes in their course work.

- Letter from Lucille Higgs, assistant, general education division, Florida State University library, April 7. 1961.

7 Letter from Katherine M. Stokes, librarian, Western Michigan University, June 20, 1961. 
The answers to questions four and five do not correlate, but the investigator refused to discard question five, for there is the possibility that if busy respondents hastily read question five and ignored the not in the wording of the question, the last question in the preceding paragraph is apropos. At the same time, the low correlation directs attention to one of the great limitations of the questionnaire method, i.e., the respondents do not always interpret and answer the questions in the same context that the investigator is considering.

Turning to question six which attempted to ascertain whether instruction in the use of the library is coordinated with the work of the library, we find that 127 or 32 per cent replied no, 181 or 46 per cent yes and 89 or 22 per cent failed to respond. It is clearly evident that the largest percentage of the respondents felt that there is real coordination between the library and the academic departments in this regard.

Librarians were requested in question seven to answer the crucial question: Do you feel that freshman library instruction should be given by members of the teaching faculty without the cooperation of the librarian and his staff? An overwhelming majority of 379 librarians or 95 per cent answered no, seven librarians or 2 per cent stated yes and eleven librarians or 3 per cent gave no response.

Librarians responded in eloquent, forthright, clear and unequivocal language, in reference to question seven. The librarian of George Peabody College for Teachers stated, "As for myself, I am rather firmly convinced that as our collections grow larger and larger, the library staff must and should be the persons designated to offer a minimum program of instruction in the use of the library." 8 The director of libraries at the University of Notre Dame pointed out that, "I disagree very strongly with

8 Letter from J. Isaac Copeland, librarian, George Peabody College for Teachers, April 17, 1961. a program that would provide freshman library instruction by members of the teaching faculty without the cooperation of the librarian and his staff." 9 Two interesting comments that were included on the questionnaire are the following: Herbert B. Anstaett, librarian of Franklin and Marshall College, gave a resounding "definitely no!" In his terse style, Guy Lyle, director of libraries, Emory University, who answered no, stated, "although it would be better than non-instruction."

The final question attempted to elicit from librarians whether there was wholehearted faculty planning and participation if the instruction was handled by the library staff. The findings showed that 170 or 43 per cent reported yes, 135 or 34 per cent stated no, and 92 or 23 per cent disregarded the question.

Many of the respondents objected to the investigator's use of the phrase "wholehearted faculty planning and cooperation." They vividly opposed the use of "wholehearted," striking through the word and substituting words which did not bespeak well of their faculties. Some of the more vocal comments on their questionnaires are as follows: Frank A. Schneider, assistant librarian of Arizona State University, wrote, "Where we have stirred interest the cooperation has been high." Joseph T. Popecki, assistant director of libraries, Catholic University, stated, "varies with the many freshman English instructors." Mrs. Mary Watson Hymon, librarian of Grambling College, wrote "wholehearted planning and participation of those involved. We do not reach the total faculty." And Sarah D. Jones, librarian of Goucher College, commented, "As new faculty members come, we have to convert them, so that degree of wholeheartedness wavers."

\section{IMPLICATIONS}

The foregoing analysis of the responses from the 397 librarians suggests serious

- Letter from Victor Schaefer, director of libraries, University of Notre Dame, March 31, 1961. 
implications regarding the extent of instruction in library use and the role of the library staff in the process. Most of the respondents (60 per cent) do not offer a required formal course in the use of the library. It may be that librarians have rejected this approach as being academically unfeasible or curriculum committees do not desire the encroachment. The small number (27 per cent) who offer the required course indicated that the course is handled by a member of the library staff.

Orientation week is used by many librarians to introduce the incoming college students to the location of the library. The largest number ( 45 per cent) that offers elementary instruction in the nature of one lecture or guided tour, and a few (19 per cent) present several lectures during this period. A growing number of librarians seem to be doing away with the orientation week approach, because of the large enrollments and the helter-skelter fiesta-type affair that characterize most orientation periods. Concerning growing enrollments, one librarian asserts "We used to give a series of lectures, but due to the rapid increase in student enrollment, the librarians found they had too much to do in such areas as building the collection, etc., to keep up with all of these lectures. . . "10 Miss Seaberg writes, "We did have for years, a tour-lecture system. As the enrollment increased and the staff load became heavier, this method seemed to get more and more mass-produced and less effective." 11 Orientation week programs seem to be less palatable. In the words of an English instructor and a college librarian, "clearly, it is not enough to arm the freshman with the floor plan of the library and urge him forward." 12

On the basis of the findings, it appears

10 Letter from Juliette A. Trainor, librarian, Paterson State College, April 5. 1961.

11 Letter from Lillian M. Seaberg, assistant librarian, University of Florida, April 6, 1961.

${ }_{12}$ Haskell M. Block and Sidney Mattis, "The Research Paper: A Co-operative Approach," College Eng. lish, XIII (January 1952) 212. that the freshman English course continues to be the traditional course for offering instruction in the use of the library, for 56 per cent reported affirmatively on this question. Many librarians while indicating some degree of cooperation from their English departments are not completely satisfied as reported in the letters referred to above. Cooperation between the library and the English department is essential, if a modicum of progress is to be experienced. This view is cogently voiced by a distinguished reference librarian who states, "I would like to emphasize that the success or failure of any program depends to a great extent upon the cooperation of the English department. We have had our good years and our poor years, depending largely, we feel quite sure, upon the enthusiasm and interest of the faculty member in charge of freshman English instruction." 13

The majority of the librarians who indicated that instruction was given in courses other than English also pointed out that the instruction was given at a time when the students were not using the library materials. We have no explanation for this situation. There is the possibility that the unit on the use of the library is sandwiched in at the most opportune time without regard for the sound educational philosophy of presenting the instruction when it will be more beneficial to the students.

The results of this study confirm this writer's belief that freshman library instruction should not be given without the cooperation of the librarian and his staff, for 379 librarians (95 per cent) asserted this fact. Librarians are better qualified by their training and knowledge of bibliographical techniques to guide the uninitiate through the maze of materials that are now housed in college and university libraries. As the writer pointed out at the beginning of

${ }^{13}$ Letter from Josephine M. Tharpe, reference librarian, Cornell University library, April 7, 1961. 
the paper, it is foolhardy to amass the highly specialized reference tools and collections and, at the same time, fail to provide instruction in the use of these materials. Many of our college freshmen come from areas where there is poor school and public library service; thus, their first experiences in the college library can be foreboding. By and large, members of the teaching faculty are not equipped to cope with this type of college freshman in the college library.

Some college instructors have become so immersed in the educational jargon of "independent study," while they have forgotten that most of our students will continue to be dependent for many years to come until we improve the public schools. A librarian who has a serious concern about instructing the average student in the skills of using the library effectively asserts, "the average or below average student, on the other hand, is likely to avoid the library, having found it a useless if not actually a terrifying place. It is not enough that he be stimulated to use the library, he must be provided with experiences which convince him that using the library is a necessary and meaningful part of education." 14

It is impossible to evade one of the serious questions raised by librarians who reported that they had dropped library instruction because of growing enrollments and shortages of staff. Increasing enrollments and staff shortages will be-

\footnotetext{
14 Patricia B. Knapp. "The Montieth Library Project: An Experiment in Library-College Relationship," $C o l$ lege and Research Libraries, XXII (July 1961) 257 . 258 .
}

come more acute as we move towards the 70's. This is a salient fact which every library administrator must consider. A solution to this problem may very well be our turning to automation, as suggested by the director of libraries at Southern Illinois University. ${ }^{15}$ In our search for alternatives and in our quest for closer cooperation with the faculty, librarians must be ever mindful that the college library is not an adjunct to teaching, it is at the very heart of the instructional process. Therefore, it is of utmost importance that college students be given the skills to use the library at the beginning of their college education.

The role of the librarian in educating the faculty to this point of view is arduous. College librarians must emphasize the following two inescapable points to their teaching colleagues. First, students' knowledge of using the library strengthens the relationship between the library and the instructional program, and second, professionally trained librarians who teach the skills of library use will not usurp the responsibilities of the faculty, but will supplement their efforts, for librarians alone are aware of the bibliographical and guidance services that the library staff is capable of offering. The essentiality of the times is the need for the integration of college libraries more completely with the curriculum, through a coordinated program of instruction in the use of the library.

15 Ralph E. McCoy, "Automation in Freshman Library Instruction," Wilson Library Bulletin, XXXVI (February 1962) 468-472. 